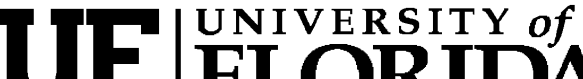 FLORIDA \\ IFAS Extension
}

SS-AGR-269

\section{Burndown of Ryegrass Cover Crops Prior to Crop Planting ${ }^{1}$}

\author{
J.A. Ferrell, D.L. Wright, B.J. Brecke, G.E. MacDonald²
}

Cover crops are commonly used after fall harvest to stabilize the soil over winter, improve soil organic matter content, and allow winter grazing on otherwise fallow ground. Many different small grain crops (oats, wheat, rye, etc) can successfully be used as a cover crop, but ryegrass is a common choice.

Ryegrass is used because it is very hardy and produces large amounts of biomass during the winter for grazing. However, if ryegrass is not successfully controlled prior to crop planting, it can become a major weed problem.

Glyphosate or Gramoxone are commonly used to burn down existing vegetation in order to provide a weed-free environment for planting. Most grasses are very sensitive to glyphosate and a single application will usually be sufficient to kill most cover crops. However, ryegrass has proven to be quite tolerant to both glyphosate and Gramoxone. Many research trials conducted across the southeast have shown that a single application of glyphosate or Gramoxone is rarely sufficient. Therefore, a program approach is generally needed to maximize ryegrass control.
Applying glyphosate at $0.75 \mathrm{lb}$ ae/A will often provide about $70 \%$ ryegrass control (Image 1 ). However, if a follow-up application is not made, it can be difficult to tell that any burndown was applied after about 2 weeks (Image 2). Increasing the glyphosate rate by $1.12 \mathrm{lb}$ ae/A can improve control, but failures at this rate are still possible, particularly during dry weather. Therefore, using a sequential application program is the best way to ensure complete ryegrass control. It is important to begin the spray program at least 10 days prior to planting to allow the herbicide sufficient time to work and regrowth to occur before the second application is made.

\section{Recommendations for Specific Crops}

For glyphosate rate conversion see Table 1.

1. This document is SS-AGR-269, one of a series of the Agronomy Department, Florida Cooperative Extension Service, Institute of Food and Agricultural Sciences, University of Florida. Original publication date April 2007. Visit the EDIS Web Site at http://edis.ifas.ufl.edu.

2. J.A. Ferrell, assistant professor, Agronomy Department; D.L. Wright, professor, North Florida Research and Education Center--Quincy; B. J. Brecke, professor, West Florida Research and Education Center--Milton FL; and G. E. MacDonald, assistant professor, Agronomy Department; Florida Cooperative Extension Service, Institute of Food and Agricultural Sciences, University of Florida, Gainesville, FL 32611.

The use of trade names in this publication is solely for the purpose of providing specific information. UF/IFAS does not guarantee or warranty the products named, and references to them in this publication does not signify our approval to the exclusion of other products of suitable composition. All chemicals should be used in accordance with directions on the manufacturer's label.

The Institute of Food and Agricultural Sciences (IFAS) is an Equal Opportunity Institution authorized to provide research, educational information and other services only to individuals and institutions that function with non-discrimination with respect to race, creed, color, religion, age, disability, sex, sexual orientation, marital status, national origin, political opinions or affiliations. U.S. Department of Agriculture, Cooperative Extension Service, University of Florida, IFAS, Florida A. \& M. University Cooperative Extension Program, and Boards of County Commissioners Cooperating. Larry Arrington, Dean 


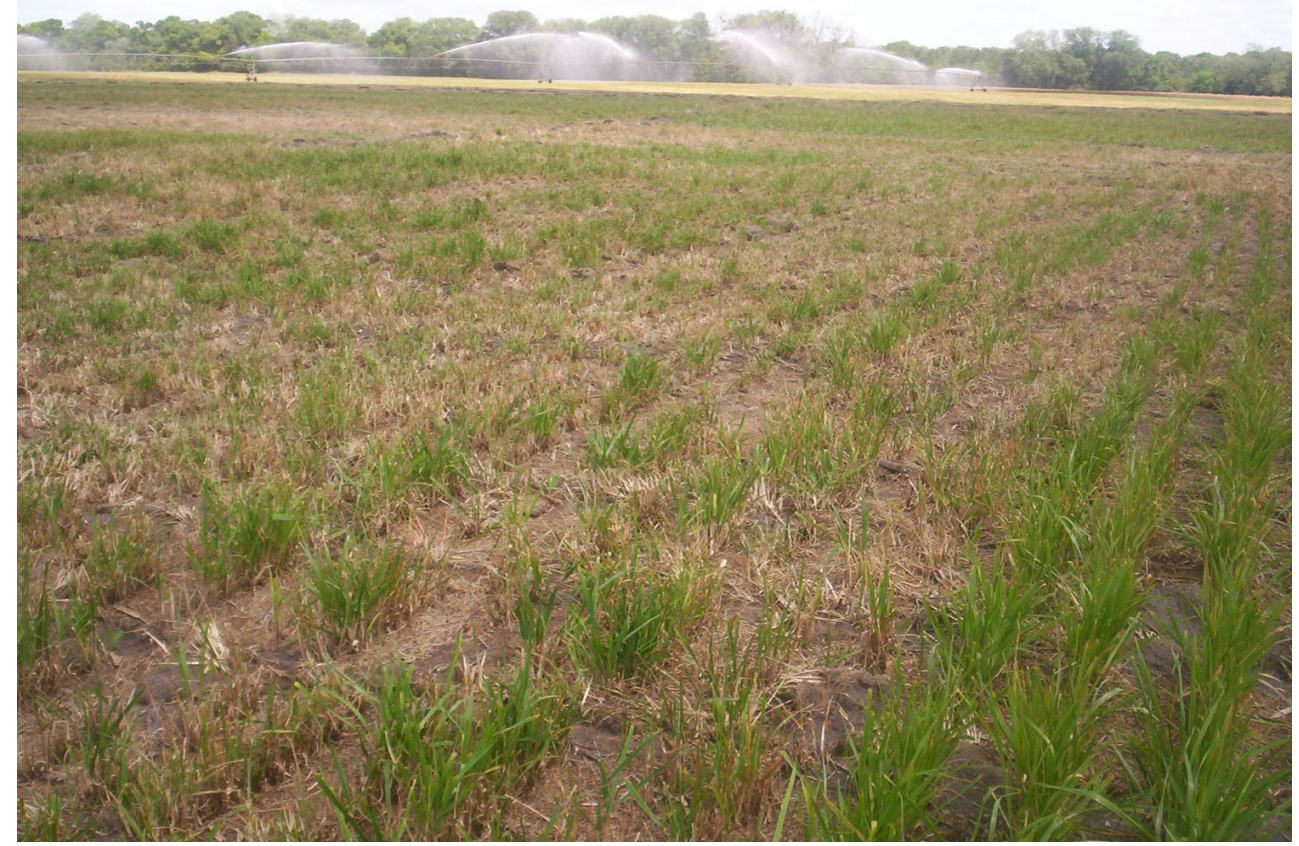

Figure 1. Ryegrass receiving one applicaton of glyphosate. Note that complete control was not achieved. Credits: Steve Williams, Albaugh Inc.

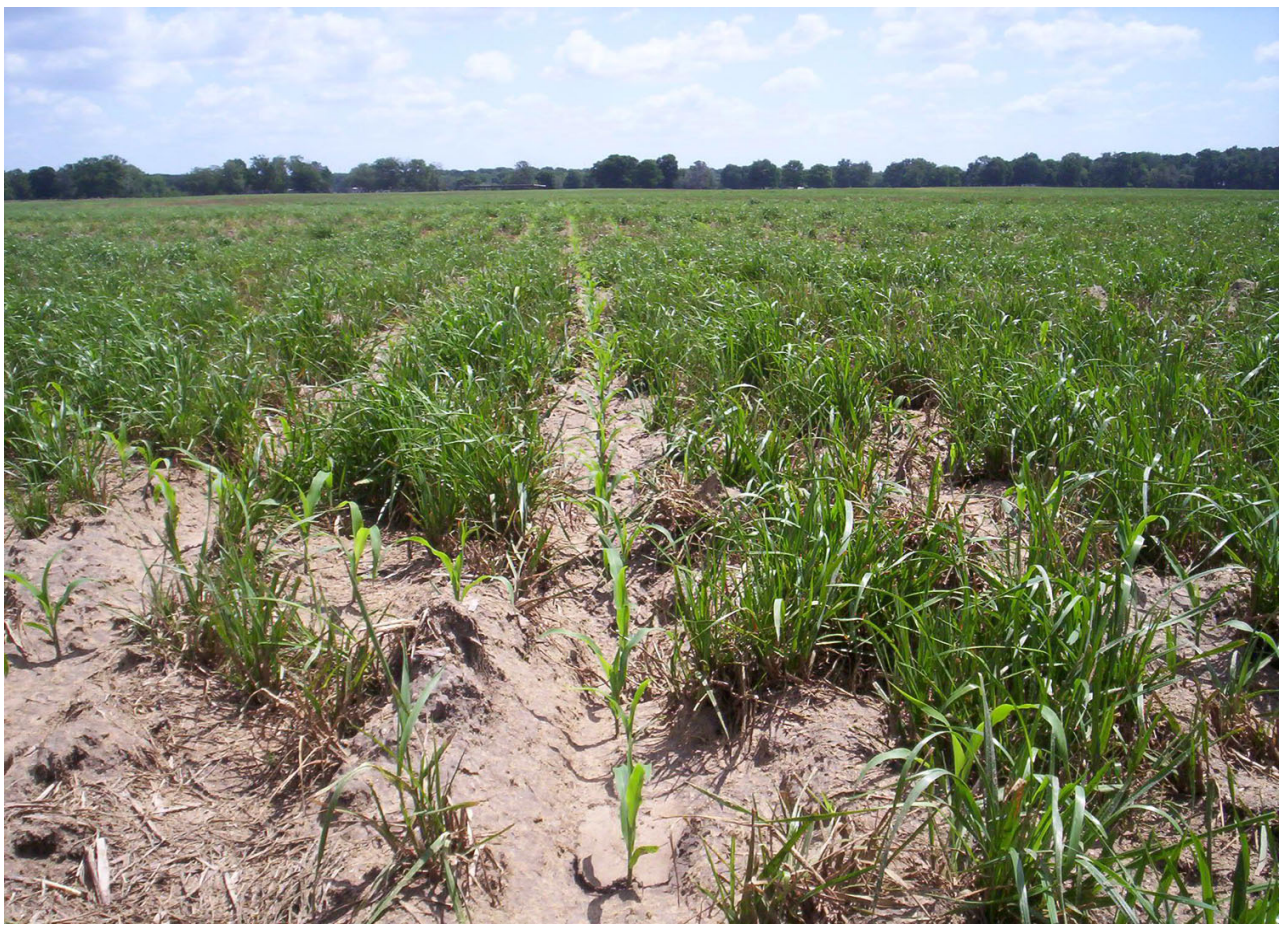

Figure 2. Ryegrass regrowth 2 weeks after receiving one applicaton of glyphosate. Regrowth has occurred and corn yield reduction will likely occur. Credits: Steve Williams, Albaugh Inc. 


\section{Corn}

Option 1. Glyphosate $0.75 \mathrm{lb}$ ae/A 10-14 days prior to planting followed by Gramoxone Inteon 1.9 $\mathrm{pt} / \mathrm{A}+$ atrazine $3 \mathrm{pt} / \mathrm{A}$.

Option 2. Glyphosate $1.12 \mathrm{lb}$ ae/A + atrazine 3 pt applied at least 7 days prior to planting.

Option 3. Gramoxone Inteon 1.9 pt/A 10-14 days prior to planting followed by Gramoxone Inteon $1.9 \mathrm{pt} / \mathrm{A}+$ atrazine $3 \mathrm{pt} / \mathrm{A}$.

It is important to use atrazine in the ryegrass control program. Atrazine possesses activity on ryegrass and although atrazine alone is not sufficient, it works well with the other herbicides to enhance control. Also, since corn is often planted in March when ryegrass is still actively growing, the additional herbicidal benefit of atrazine is needed.

\section{Cotton or Peanuts}

Option 1. Glyphosate $0.75 \mathrm{lb}$ ae/A $10-14$ days prior to planting followed by Gramoxone Inteon 1.9 $\mathrm{pt} / \mathrm{A}$.

Option 2. Glyphosate $0.75 \mathrm{lb}$ ae/A $10-14$ days prior to planting followed by glyphosate $0.75 \mathrm{lb}$ ae/A.

Table 1. Conversion of glyphosate rates based on product formulations.

\begin{tabular}{||l|c|c||}
\hline \hline Brand & $0.75 \mathrm{lb}$ ae/A & $1.12 \mathrm{lb}$ ae/A \\
\hline $\begin{array}{l}\text { 3 lb ae/gal } \\
\text { ClearOut, Cornerstone, Credit, Glystar, Glyfos, } \\
\text { Glyphomax, Glyphosate 4, Honcho, Rattler, } \\
\text { Razor, Roundup Original, Touchdown }\end{array}$ & $32 \mathrm{fl.} \mathrm{oz} / \mathrm{A}$ & $48 \mathrm{fl.} \mathrm{oz/A}$ \\
\hline$\frac{4 \mathrm{lb} \text { ae/gal }}{\text { Glystar 5, Glypro }}$ & & \\
\hline$\frac{4.5 \mathrm{lb} \text { ae/gal }}{\text { Roundup Weathermax }}$ & $24 \mathrm{fl.} \mathrm{oz/A}$ & $36 \mathrm{fl} . \mathrm{oz} / \mathrm{A}$ \\
\hline \hline
\end{tabular}

